\title{
CONDUCT OF LAWS: NATIVE TITLE, RESPONSIBILITY, AND SOME LIMITS OF JURISDICTIONAL THINKING
}

\author{
ShaUnNagh DORSETT $^{*}$ AND SHAUn MCVEIGH $^{\dagger}$
}

[It is now twenty years since the High Court of Australia designated 'native title' as the site of engagement of Australian common law and jurisprudence with Indigenous law and jurisprudence in Mabo v Queensland [No 2]. Common law jurisprudence, however, continues to struggle to create the appropriate form and conduct of the relations between itself and Indigenous laws and jurisprudence. It struggles, in short, to create an appropriate meeting place of laws. In light of recent attempts to amend the Native Title Act 1993 (Cth), it is timely, then, to return to the first question that is addressed in the meeting of laws in Australia, that of the authorisation of laws and the quality and conduct of the meeting place. Here the meeting of Australian common law and Indigenous law in Australia is tracked in terms of a brief history of common law jurisdictional practice, the jurisprudence of the conduct of lawful relations in and through s 223 of the Native Title Act, and official forms of responsibility for lawful relations.]

\section{CONTENTS}

I Introduction 471

II Jurisdiction. 473

III A Meeting of Jurisdictions and of Laws....... 475

IV Conduct of the Meeting Place. 479

V The Quality of Meeting 485

VI The Meeting Places of the Jurisprudent. 489

VII Concluding Comments 492

* BA, LLB (Hons) (Tas), LLM (Calg), PhD (UNSW); Associate Professor, Faculty of Law, University of Technology, Sydney.

${ }^{\dagger}$ LLB (Hons) (Exe); Associate Professor, Melbourne Law School, The University of Melbourne. 


\section{INTRODUCTION}

It is now 20 years since the High Court of Australia designated 'native title' as the site of engagement of Australian common law and jurisprudence with Indigenous law and jurisprudence in Mabo $v$ Queensland [No 2] ('Mabo'). ${ }^{1}$ Common law jurisprudence, however, continues to struggle to create an appropriate form and conduct of the relations between itself and Indigenous laws and jurisprudence. It has struggled, in short, to create an appropriate meeting place of laws. It is timely, then, to return to the first question that is addressed in the meeting of laws in Australia, that of the jurisdictional authorisation of laws and the quality and conduct of the meeting place of law. In this essay we address this concern as a question of the conduct of lawful relations.

An image of the meeting of laws, and of a meeting place of laws, can be quite direct and simple. It could be imagined as two people meeting, acknowledging, and engaging a lawful relation. It can also be more mediated. In Western legal idioms, a meeting place can be figured through the arrangements of the sacred meeting places of religious life, or the deliberative, affective, and profane meeting places of the court, the theatre, or the market of the city or state. It could also be the diplomatic space of meeting or the 'free' space between laws that has characterised some accounts of international law. The image of the meeting place is valuable, even if it is difficult to concepttualise, because it allows us to understand something of the meaning of the conduct of lawful relations.

For those who live with the idioms of the common law tradition there are a number of established forms of engagement of the conduct of lawful relations between peoples and laws - such as through treaty making or through dispossession. Relations between laws could be phrased in terms of a very limited engagement - where engagement is simply a matter of how one jurisdiction satisfies itself of the relevance (or not) of another. An engagement of laws could also be concerned with the processes, protocols, and procedures that create and arrange relations of laws. In the case of the engagement of laws, it could mean the acknowledgement of and contribution to the creation of a middle ground, or a meeting place, of laws. While a meeting point of law might suggest the observation of the meeting of laws, a meeting place directs attention to the understanding of the quality or character of the meeting.

In this essay we track the formation of a meeting place of law in terms of practice of jurisdiction and the conduct of lawful relations. Specifically, this

1 (1992) 175 CLR 1. 
essay addresses the Australian common law understanding of the meeting of laws as one of a meeting of jurisdictions. We concentrate on the ways in which speaking and acting in the name of law are related to the ways in which we take responsibility, as jurists and jurisprudents, for both the interior or inner experience of the common law and the outer, practical reality of law. ${ }^{2}$ The specific engagement of this essay is with the meeting of laws established through the regimes of native title and specifically s 223 of the Native Title Act 1993 (Cth) ('NTA'). We give shape to the forms of conduct of lawful relations across three registers.

The first register joins the meeting of laws to a longer tradition of AngloAustralian common law elaborating the meeting points of laws in Australia. In many ways s 223 of the NTA has become the exemplary point of engagement of the common law with Indigenous laws in Australia. However, that section, and native title legislation in general, belongs to a longer - plural history of jurisdictional engagement of laws. The second register is jurisprudential and is concerned with the crafting of lawful relations. Native title jurisprudence has established the repertoires, ideas, and institutional arrangements through which the meeting of laws and the maintenance of lawful relations are conducted. We draw out the sense in which s 223 is concerned with the conduct of lawful relations by attending to the grammar of legal relations. Native title is often phrased in adjective terms as being concerned with proof and procedure. Here we point to the ways in which it might be considered as adverbial and concerned with the quality of conduct. Native title does not describe or name the conditions of the meeting of law, it provides the mode or manner of the conduct of the meeting of law. A third register of the meeting of laws is addressed in terms of responsibility for the conduct of law. It returns responsibility for the conduct of the meeting of laws to the office of the jurist and jurisprudent as these offices have specific obligations for the care of the shape and conduct of law. ${ }^{3}$

In drawing out the jurisdictional character of native title and an ethic of responsibility appropriate to such forms, we are not directly concerned with establishing new normative relations. We are more concerned with the modes

2 See generally Peter Cane, Responsibility in Law and Morality (Hart Publishing, 2002); Scott Veitch, Law and Irresponsibility: On the Legitimation of Human Suffering (RoutledgeCavendish, 2007).

3 See, eg, Conal Condren, 'The Persona of the Philosopher and the Rhetorics of Office in Early Modern England' in Conal Condren, Stephen Gaukroger and Ian Hunter (eds), The Philosopher in Early Modern Europe: The Nature of a Contested Identity (Cambridge University Press, 2006) 66-7. 
and manner of relating of one law to another and of the shape given to the engagement of common law and its jurisprudence with Indigenous law and jurisprudence. ${ }^{4}$ We do so to draw out the sorts of commitments made within common law jurisprudence to the conduct of relations in the meeting of laws. We present these questions of conduct in terms of lawfulness rather than, say, dignity, in order to emphasise the ways in which questions of conduct involve questions of institutional practice, judgment, and responsibility.

\section{JURISDICTION}

This article addresses the conduct of the meeting of laws through the concerns of jurisdiction. Jurisdictional thinking can be considered as engaging with questions of the authority of law (whose law is to be followed?) as well as the authorisation of lawful relations (who or what belongs to law?) and the conduct of lawful relations. Viewed from the perspective of the common law tradition the meeting of the common law and Indigenous laws uses all three of these aspects of jurisdiction. ${ }^{5}$

A starting point for our thinking about jurisdiction comes from Peter Rush, who writes that jurisdiction 'refers us first and foremost to the power and authority to speak in the name of law and only subsequently to the fact that law is stated - and stated to be something or someone.' ${ }^{\prime 6}$ From this, and from the word 'jurisdiction' itself, we can take two things. First, jurisdiction connotes authority. ${ }^{7}$ Second, it is the act of speaking — of declaring the law. 'Jurisdiction' is derived from the Latin ius dicere - literally 'to speak the law'.

4 This terminology is borrowed from Christine Black, The Land Is the Source of the Law: A Dialogic Encounter with Indigenous Jurisprudence (Routledge, 2011).

5 On jurisdiction generally, see Shaunnagh Dorsett and Shaun McVeigh, Jurisdiction (Routledge, 2012).

6 Peter Rush, 'An Altered Jurisdiction: Corporeal Traces of Law' (1997) 6 Griffith Law Review $144,150$.

7 Similarly, Coke (one of the few common law jurists to try to define jurisdiction) stated that 'jurisdiction is the authority to decide or give judgment among parties concerning actions to be taken over people and property ... Jurisdiction is the power to give judgment on a public matter, and is instituted by necessity': Sir Edward Coke, The Fourth Part of the Institutes of the Laws of England: Concerning the Jurisdiction of Courts (Lee and Pakeman, 1648) preface. See also The Case of the Marshalsea (1612) 10 Co Rep 68b, 73a; 77 ER 1027, 1033 (Coke CJ). Coke himself excerpted this quote from the mediaeval jurist Azo. However, when he did so, Coke left out a few words at the end: 'and of establishing equity'. This is interesting because it reminds us that there are rival forms of authority and rival positions, as well as the contested nature of thinking with conscience: see generally Peter Goodrich, 'Visive Powers: Colours, Trees and Genres of Jurisdiction' (2008) 2 Law and Humanities 213. 
Thus, jurisdiction is the practice of pronouncing the law. Jurisdiction engages law in a variety of ways. Perhaps most importantly, it gives us both the form and shape of law and the idiom of law. Jurisdiction in this respect forms a part of the discourse of sovereignty.

Importantly, jurisdiction can also be viewed as part of the technical ordering of lawful relations. Jurisdictional knowledge is, in a sense, the practical knowledge of how to do things with law. Thus, in this article we use jurisdiction in a rather more expansive jurisprudential mode than is usually found in doctrinal formulations of jurisdiction in procedural and administrative law. Jurisdiction is not only concerned with the authority of law but with the authorisation of lawful relations. The practice of jurisdiction is part of the technique and craft of legal ordering and the art of creating legal relations. For present purposes the terms practice and craft simply indicate that jurisdiction is not just a descriptive concept - but rather that jurisdiction, through institutions, actively works to produce something. So, as a practice, the idioms of jurisdiction concern the means of ordering law. For example, they create the practical organisation of the business of the courts and the management of the scope or extent of authority to judge. Without such modes of thinking about law there would be no way of engaging with law as a practical activity with purpose. Considering jurisdiction in the crafting of lawful relations shapes our approach to the meeting of laws.

Thinking jurisdictionally is not a new approach to thinking about relations between laws. As we will discuss further, the common law has long understood the ordering of its relations to other laws as being a matter of jurisdiction (for example, common law and ecclesiastical law or common law and forest law). Likewise, viewed from this perspective native title and its administration can be understood in terms of the conduct of a meeting of law. Such an approach focuses on how laws meet - here the common law and Indigenous laws - rather than on the doctrinal content of native title. The doctrine of native title provides the rules according to which the common law will recognise native title for its own purposes. However, that doctrine tells us little about how the common law relates to other laws or the mode and manner of their meeting. It is by framing the meeting of laws in terms of conduct that it becomes possible both to acknowledge the continuing plurality of laws and to consider our responsibility for the way in which laws meet and for the form of native title doctrine. 


\section{A MEETING OF JURISDICTIONS AND OF LAWS}

The Anglo-common law has a long tradition of engaging laws. We tend to lose sight of this if we think of laws as expressed only in terms of sovereign territorial states. In this section we briefly rehearse a doctrinal history of the arrival of the Anglo-common law to Australia. To draw out the sense that the meeting of laws is, in part, a matter of practical ordering of legal relations within the common law tradition, we rephrase the meeting of laws in terms of jurisdiction and the ways in which the meeting of law is practiced.

Within Australian common law doctrine, native title has been represented as a point of intersection between the common law and multiple Indigenous jurisdictions. To some, particularly commentators like Noel Pearson, this was obvious back in the $1990 \mathrm{~s}^{8}$ In recognising native title, the decision in Mabo created a relationship between two laws - those of the Meriam people and that of the common law of the Australian nation. To some extent, the High Court of Australia itself recognised that a relationship between two laws had been created, although it was clear from the beginning that this relationship was not necessarily from the perspective of that Court one of legal equals. However, the High Court has not been able to articulate with much clarity the nature of the relationship between these laws or the manner in which they engage. Famously, according to Brennan J, '[n]ative title has its origins in and is given its content by the traditional laws acknowledged by and the traditional customs observed by the indigenous inhabitants of a territory. ${ }^{9} \mathrm{Or}$, as expanded in Fejo $v$ Northern Territory, '[n] ative title is neither an institution of the common law nor a form of common law tenure but it is recognised by the common law'. ${ }^{10}$ More directly, in Wik Peoples $v$ Queensland ('Wik'), ${ }^{11}$ in the context of the effect of extinguishment, Kirby J reminded us that even if native title were extinguished at common law it might continue under Indigenous law. The ceasing of recognition at common law, he noted, 'does not mean that,

${ }^{8}$ In Pearson's formulation native title is not 'of' the common law, neither is it 'of' Indigenous law. Consequently, '[n] ative title is therefore the space between the two systems, where there is recognition. Native title is [for] want of a better formulation the recognition space [between] the common law and the Aboriginal law which [afforded] recognition in particular circumstances': Noel Pearson, 'The Concept of Native Title at Common Law' (1997) 5 Australian Humanities Review <http://www.australianhumanitiesreview.org/archive/Issue-March -1997/pearson.html>.

9 Mabo (1992) 175 CLR 1, 58.

10 (1998) 195 CLR 96, 128 [46] (Gleeson CJ, Gaudron, McHugh, Gummow, Hayne and Callinan JJ).

11 (1996) 187 CLR 1. 
within in its own world, native title (or any other incidents of the customary laws of Australia's indigenous peoples) depends upon the common law for its legitimacy or content.' ${ }^{2}$ So, one starting point for the consideration of the conduct of laws lies with the historical formulation of forms of jurisdictional engagement. It is these practices, or those we acknowledge, that provide the repertoires of the jurisdictional engagement of laws - and give shape to the forms of responsibility for the practice of a jurisdiction.

The idea that native title is a meeting point ought not to be difficult for either lawyers or historians concerned with the history of Indigenous peoples' engagement with English common laws. However, it has not always been easy to see that the meeting of laws - within a Western idiom - is also an intersection of jurisdictions and a practice of jurisdiction. Such meetings, of course, have taken place and continue to take place in a variety of ways. It is in the colonial context perhaps that it is easiest to see the legal relations between Indigenous and non-Indigenous peoples conducted as matters of jurisdiction. Much of the discussion of common law jurisdiction in relation to Indigenous peoples and Indigenous laws in recent years has taken place through an examination of the historical encounters between Indigenous Australians or Māori and the Crown (in its various guises). ${ }^{13}$ It is in the early colonial period that the common law can be seen most clearly as having a material form and practice of a jurisdictional engagement of jurisdictions.

In Australia, British imperial and colonial modes of sovereignty have been traced to the key period of the beginning of the $19^{\text {th }}$ century and the rise of territorial sovereignty and the accompanying association of jurisdiction with this legal form. For those interested specifically in the relationship between territorial sovereignty and the 'recognition' of Indigenous jurisdictions in the colony of New South Wales, a 'key moment' might be the mid-1830s and the

12 Ibid 213.

13 See, eg, P G McHugh, Aboriginal Societies and the Common Law: A History of Sovereignty, Status, and Self-Determination (Oxford University Press, 2004); Lisa Ford, Settler Sovereignty: Jurisdiction and Indigenous People in America and Australia, 1788-1836 (Harvard University Press, 2010); Mark D Walters, 'The Extension of Colonial Criminal Jurisdiction over the Aboriginal Peoples of Upper Canada: Reconsidering the Shawanakiskie Case (1822-26)' (1996) 46 University of Toronto Law Journal 273; Damen Ward, 'Constructing British Authority in Australasia: Charles Cooper and the Legal Status of Aborigines in the South Australian Supreme Court, c 1840-60' (2006) 34 Journal of Imperial and Commonwealth History 483; Shaunnagh Dorsett, 'Sworn on the Dirt of Graves: Sovereignty, Jurisdiction and the Judicial Abrogation of "Barbarous" Customs in New Zealand in the 1840s' (2009) 30 Journal of Legal History 175. 
decision in $R v$ Murrell ('Murrell') in particular. ${ }^{14}$ The cases in that period centred on the question of whether Indigenous people had an established system of law. In Ballard, the Court determined that the common law had no jurisdiction. ${ }^{15}$ However, from 1836 onwards, in a series of now well-known decisions - particularly Murrell, $R v$ Neddy Monkey and $R v$ Cobby - the courts almost consistently came to the opposite conclusion. ${ }^{16}$ For some, Murrell marked a turning point as it subjected Indigenous people to a personal jurisdiction of the laws of crime through the instantiation of territorial sovereignty/jurisdiction. ${ }^{17}$ From this point it is possible to chart the displacement of the common law engagement with a plurality of law.

Examined through a jurisdictional idiom, however, a slightly different reading of that 'key moment' in the 1830s emerges. First, there is little doubt that by the 1830s the idea of territorial sovereignty/jurisdiction had well taken hold, first in Europe and then in various contexts in various times and places across the Empire. ${ }^{18}$ However, what it did not lead to was the demise of the plurality of laws. The failure of the Court in Murrell to continue to deny common law jurisdiction over matters inter se did not end the plurality of laws. It simply changed the terms of jurisdictional engagement. This shifting of the legal meeting point has occurred a number of times in the history of legal relations in Australia between Indigenous and non-Indigenous.

In the contemporary context of native title it is less easy to see legal relations between Indigenous and non-Indigenous as a matter of jurisdiction. Within legal doctrine there has been a change in the traditional language of legal authority. Where once legal authority was articulated through the language of jurisdiction, that language has been supplanted by that of sovereignty. This can be seen in most High Court judgments of the early period. As stated in Western Australia $v$ Ward ('Ward'): 'The assertion of sovereignty marked the imposition of a new source of authority over the land. ${ }^{19}$ From the mid-1800s onwards, questions of jurisdiction and of the engagement of laws

14 (1836) 1 Legge 72. See also Bruce Kercher, ' $R v$ Ballard, $R v$ Murrell and $R v$ Bonjon' (1998) 3 Australian Indigenous Law Reporter 410, 414.

${ }^{15} R v$ Ballard or Barrett (Unreported, Supreme Court of NSW, Forbes CJ and Dowling J, 13 June 1829).

${ }^{16} R v$ Neddy Monkey (1861) $1 \mathrm{~W} \& \mathrm{~W} 40 ; R v$ Cobby (1883) 4 LR (NSW) 355.

17 Shaunnagh Dorsett, "'Since Time Immemorial”: A Story of Common Law Jurisdiction, Native Title and the Case of Tanistry' (2002) 26 Melbourne University Law Review 32, 51.

18 See generally Ford, above n 13, 3-9; McHugh, Aboriginal Societies and the Common Law, above n 13, 61-3.

19 (2002) 213 CLR 1, 94 [91] (Gleeson CJ, Gaudron, Gummow and Hayne JJ). 
largely disappeared. Post-Mabo, and despite the historical work generated about the colonial period, lawyers think little about this early history, or even of the place of jurisdiction in our legal system. This is predominantly because the language of native title decisions is that of sovereignty not jurisdiction. ${ }^{20}$ Further, the demise of jurisdiction generally as a way of thinking about how we organise our own legal ordering makes it even less likely that we will conceive of modern native title doctrine as a form of jurisdictional practice. The doctrinal instantiation of sovereignty as the language of legal authority was (to the extent there was any doubt post-Mabo) completed in Members of the Yorta Yorta Aboriginal Community $v$ Victoria ('Yorta Yorta'). ${ }^{21}$ For the High Court, the form of meeting was between two 'normative systems'. ${ }^{22}$ All judgments proceeded from an understanding that native title constitutes the point of intersection between two laws, or normative systems: Aboriginal law and common law. ${ }^{23}$ Absent a discussion of jurisdiction, the High Court in Yorta Yorta redescribe and confuse the meeting of laws by fixing on the question of sovereignty. According to the High Court, interests created after this meeting by one system (Indigenous or Aboriginal law) would not 'be given effect by the legal order of the new sovereign' (the common law). ${ }^{24}$ The assertion of sovereignty by the British Crown 'necessarily entailed' that thereafter there could be 'no parallel law-making system in the territory over which it asserted sovereignty. To hold otherwise would be to deny the acquisition of sovereignty and ... that is not permissible. ${ }^{25}$ Two ways of engaging the plurality of laws are seemingly possible for Australian common law after Yorta Yorta. The first is that as a result of that decision there is no Indigenous or Aboriginal law as such post-sovereignty, merely a normative system which is less than law, maybe custom, in which case no meeting point between laws is possible. Or, second, there are laws, but they run in parallel to the common law, and hence never meet our laws unless a non-legal meeting point is built between them. Such a meeting point might, perhaps, be ethical,

${ }^{20}$ For an example of a scholar who does not view the matter as simply one of sovereignty see Rush, above n 6, 163-6. See also Edward Mussawir, Jurisdiction in Deleuze: The Expression and Representation of Law (Routledge, 2011) ch 6.

21 (2002) 214 CLR 422.

${ }^{22}$ Ibid 441 [39] (Gleeson CJ, Gummow and Hayne JJ).

${ }^{23}$ Ibid 439 [31], citing Fejo v Northern Territory (1998) 195 CLR 96, 128 [46] (Gleeson CJ, Gaudron, McHugh, Gummow, Hayne and Callinan JJ).

24 Yorta Yorta (2002) 214 CLR 422, 443 [43] (Gleeson CJ, Gummow and Hayne JJ).

25 Ibid 444 [44]. See also Shaunnagh Dorsett and Shaun McVeigh, 'An Essay on Jurisdiction, Jurisprudence, and Authority: The High Court of Australia in Yorta Yorta (2001)' (2005) 56 Northern Ireland Legal Quarterly 1. 
social or governmental. The consequence of this, however, would be to lose the question of authority in the meeting of laws.

In this part of the essay we have argued for the continuing importance of attending to questions of jurisdiction. It is through questions of jurisdiction that it is possible to address most clearly questions of authority and responsibility for the conduct of law. It is the forms of jurisdictional arrangement that give us repertoires of lawful engagement, and hence through which we practice responsibility for (our) law. Framing the meeting of laws in terms of sovereignty, we have argued, suggests that questions of authority have already been determined and that questions of plurality have been largely addressed. This hardly seems the case yet in Australia.

\section{Conduct of the Meeting Place}

In the last section we considered the institutional and historical forms of the conduct of the meeting of law. In this section and the next we attend to the jurisprudence of the meeting of laws and the quality of the conduct of lawful relationships imagined by the common law. We do this by linking questions of jurisprudence to those of jurisdiction. While native title is an area of law that has been studied intensely, as indicated in the last section, it has rarely been addressed as a concern of the conduct of a jurisdictional practice. The character of the meeting of the common law and Indigenous laws in Australia has become quite specific. Section 223 of the NTA has in many respects become the model of the engagement of laws. What is addressed here is an account of the conduct of such relations. To do this we draw out the sense in which s 223 has taken on an operational quality rather than being addressed as a definitional section. ${ }^{26}$ In the next section of this essay we look to the ways in which the operational quality of s 223 is shaped by the conduct of jurisdiction. To do this we look specifically at how s 223 can be understood as a device of jurisdiction. Thinking about the ways in which laws meet, and the quality of their encounter, allows us to understand something of the jurisdiction of native title. It also provides a way of drawing out the limits of legal engagement expressed within Australian common law.

Section 223 defines native title. Relevantly, s 223(1) provides that:

26 Section 223 obviously does not exist in isolation from other key provisions of the Act, in particular, for example, s 225. However, this essay draws on s 223 in order to focus on the jurisdictional qualities of the encounter. 
(1) The expression native title or native title rights and interests means the communal, group or individual rights and interests of Aboriginal peoples or Torres Strait Islanders in relation to land or waters, where:

(a) the rights and interests are possessed under the traditional laws acknowledged, and the traditional customs observed, by the Aboriginal peoples or Torres Strait Islanders; and

(b) the Aboriginal peoples or Torres Strait Islanders, by those laws and customs, have a connection with the land or waters; and

(c) the rights and interests are recognised by the common law of Australia. $^{27}$

While it is not, as such, an 'operational' section of the Act (relevantly that is s 61), its interpretation over more than a decade, predominantly by the Federal Court, has had significant effects on native title doctrine. In Ward and Yorta Yorta, the High Court mandated that post the enactment of the NTA, ' $[a] n$ application for determination of native title requires the location of that intersection [between common law and Indigenous law and custom], and it requires that it be located by reference to the Native Title Act. ${ }^{\text {'2 }}$ Further, '[a]s has been pointed out above, what the claimants sought was a determination that is a creature of that Act, not the common law. ${ }^{29}$ The Court itself, therefore, effectively relocated the meeting point to $s 223 .^{30}$

In a conventional sense, s 223 is a definitional section (located in pt $15-$ 'Definitions'). This section then determines what can be recognised as the content of native title. Section 223 was designed to negotiate the relationship between statute and the common law, not the common law and Indigenous jurisdictions. Every aspect of s 223 has been subject to interpretation. Each of the words and phrases in the section has been interpreted, both individually and in relation to each other. Over the last decade, the continual tightening of the interpretation of these words in s 223 has crafted a 'fragmented' or highly

27 Emphasis in original.

28 Yorta Yorta (2002) 214 CLR 422, 439 [31] (Gleeson CJ, Gummow and Hayne JJ). See also Ward (2002) 213 CLR 1, 65-6 [16], 69 [25] (Gleeson CJ, Gaudron, Gummow and Hayne JJ).

29 Yorta Yorta (2002) 214 CLR 422, 440 [32] (Gleeson CJ, Gummow and Hayne JJ).

${ }^{30}$ As commentators such as Pearson and Strelein have pointed out, at a doctrinal level this has had a significantly restrictive effect on the scope of native title outcomes. Lisa Strelein, Compromised Jurisprudence: Native Title Cases since Mabo (Aboriginal Studies Press, 2006); Noel Pearson, Up from the Mission: Selected Writings (Black Inc, 2009). It has probably also contributed to a decision on the part of plaintiffs to avoid litigated processes, in favour of consent determinations. 
individuated view of Indigenous law through native title. ${ }^{31}$ This is accentuated by the requirement in s 225(b) that the determination elaborate the 'nature and extent of the rights and interests'. One result of this has been that the staging of the meeting point of common law and Indigenous laws is not directly as a question of jurisdiction but in terms of whether traditional laws and customs exist. This, in turn, makes the consideration of the meeting of laws harder to see as a concern of conduct. Here we briefly take up the example of how 'rights and interests' (a matter which in any case can never be separated entirely from other phrases in the section) might be considered as part of the conduct of a relationship of laws.

'Rights and interests' and 'in relation to' have been the subject of elaboration in a number of decisions. ${ }^{32}$ At the time of the decision in Mabo one of the matters that received attention was the nature of native title as property or not. In that decision Brennan J equivocated as to whether native title could be proprietary. ${ }^{33}$ It is still a question asked in some standard land law texts. Some continue to advocate that if native title is not proprietary it should be recognised as such. ${ }^{34}$ Two related matters maintain the connection between questions of property and native title. The first is the early analogising of native title to the dominant 'bundle of rights' metaphor of property. ${ }^{35}$ The second is the use of the words 'rights and interests', 'in relation to' and 'land and waters'. Together these continue to significantly affect the scope of native title outcomes. This is particularly so given the definition of 'rights and interests' in s 223(2) (includes, but is not limited to 'hunting, gathering,

31 Key phrases include 'communal, group or individual' (the so-called 'chapeau' to s 223); 'rights and interests ... in relation to land or waters' (chapeau); 'traditional laws acknowledged' and 'traditional customs observed' (s 223(1)(a)); and 'connection' (s 223(1)(b)). Problematically, none of these phrases are themselves defined in the Act (in line with the original intention that the section be a 'conduit' between the common law and the Act). Although it is necessary to note the partial definition of 'rights and interests' in s 223(2). For a history of this 'tightening', see P G McHugh, Aboriginal Title: The Modern Jurisprudence of Tribal Land Rights (Oxford University Press, 2011).

32 See, eg, Wik (1996) 187 CLR 1; Fejo v Northern Territory (1998) 195 CLR 96; Yanner v Eaton (1999) 201 CLR 351; Commonwealth v Yarmirr (2001) 208 CLR 1; Ward (2002) 213 CLR 1; Wilson v Anderson (2002) 213 CLR 401; Yorta Yorta (2002) 214 CLR 422.

33 Mabo (1992) 175 CLR 1, 51, 61.

34 See, eg, Noel Pearson's call for native title to be recognised as the most basic Anglo-common law proprietary interest in land - the estate in fee simple: Noel Pearson, 'A Brief Overview of the "Problem" and "Land is Susceptible of Ownership" in Honour among Nations' (Paper delivered at the Section 223 Native Title Act Workshop, Melbourne Law School, 14 May 2009).

35 For the origin of this term see Yanner v Eaton (1999) 201 CLR 351, 365-6 [17] (Gleeson CJ, Gaudron, Kirby and Hayne JJ). 
fishing'). For doctrinal lawyers, one way of thinking about this would be as a matter of legal categories. The classic example might be Bulun Bulun $v R$ \& $T$ Textiles Pty Ltd, in which von Doussa J in the Federal Court held that native title could not include matters such as cultural knowledge (here designs used on a tea towel) because of the inseparable nature of ownership in land and ownership in artistic works.' ${ }^{36}$ To do so would, in Brennan J's terms, 'fracture the skeleton' of the common law. ${ }^{37}$ One is a matter of real property law, the other of intellectual property. ${ }^{38}$ Thinking about native title through the lens of legal categories (itself a jurisdictional task that shapes legal relations) is not unimportant, and could tell us much about the shape of our doctrine as well as about the jurisdictional form of native title. However, in recent years not even this has happened. Rather, 'rights and interests' has been represented as a matter of describing 'social practices' or 'custom' to a sufficient level of proof for recognition. ${ }^{39}$

One example of the way in which the interpretation of 'rights and interests' in s 223 occludes the conduct and relationship of laws can be seen in the courts' consideration of whether a 'right to speak for country' is a relevant 'right or interest'. This is phrased (in a kind of property language) as nonspecific non-usufructuary claims within the ambit of s 223. In Lardil Peoples $v$ Queensland ('Lardil Peoples') ${ }^{40}$ for example, the claim included the right to speak for an area offshore. Cooper J noted that:

to state the right as ' $a$ right to speak for Country' lacks the precision required by the Act. In fact it is the expression of a concept which embraces a 'bundle of rights' varying in number and kind, which may or may not be capable of full or

36 (1998) 86 FCR 244, 256.

37 Mabo (1992) 175 CLR 1, 29, cited in ibid.

38 This limited view of the scope of native title was criticised by Kirby J in Ward (2002) 213 CLR 1,247 [580] (citations omitted):

In evidence, the Ningarmara appellants described the 'land-relatedness' of their spiritual beliefs and cultural narratives. Dreaming Beings located at certain sites, for example, are narrated in song cycles, dance rituals and body designs. If this cultural knowledge, as exhibited in ceremony, performance, artistic creation and narrative, is inherently related to the land according to Aboriginal beliefs, it follows logically that the right to protect such knowledge is therefore related to the land for the purposes of the NTA.

However, any chance to think beyond this limitation was lost through the reinforcement of the grid of common law categories under the terms of s 223 of the NTA.

39 See, eg, Ward (2002) 213 CLR 1, 91 [82] (Gleeson CJ, Gaudron, Gummow and Hayne JJ).

40 [2004] FCA 298 (23 March 2004). 
accurate expression as rights to control what others may or may not do with the land and waters.$^{41}$

Rather than a recognition of a right of custodianship for country, or of a right to participate in decision-making with respect to the area, Cooper J transformed this into a question of right to access or right to control access to the claimed area. The judgment further fragmented or individuated the reasons for which access would be allowed, most of which boiled down to hunting and fishing (for subsistence) and ceremonial purposes. ${ }^{42}$ Such claims, however, continue to be made by claimants, although more generally phrased now as a 'right to protect'. In Sampi v Western Australia, for example, the right claimed was 'the right to care for, maintain and protect the sea, including its places of spiritual or cultural significant $\left[\right.$ sic] ${ }^{43}$ The trial judge indicated that: 'I do not consider the claimed right to "care for, maintain and protect the land ..." defines with any useful precision the nature of the entitlement which it confers or the activities which it will authorise. ${ }^{44}$

In the recent Akiba $v$ Queensland [No 2] ('Akiba'), the claimants claimed 'rights "to protect resources", "to protect the habitat of resources" and "to protect places of importance"' ${ }^{45}$ As in Lardil Peoples this was contentious for two reasons: first, how was it to be understood as an issue of control and access; second, was it sufficiently precise to be a 'right'? For Finn J (and counsel for Akiba) 'protect' could not be separated from 'control. According to Finn J:

There is evidence that the Islanders have engaged, and do engage, in resource conservation measures and have an awareness of the inter-generational need for this. There equally is some evidence of lawful remonstration against outsiders and Islanders from more distant places, who were engaging in practices which were considered to be likely to deplete resources or to harm habitat ... ${ }^{46}$

41 Ibid [71], citing Ward (2002) 213 CLR 1, 95 [95] (Gleeson CJ, Gaudron, Gummow and Hayne JJ) (emphasis in original).

42 Lardil Peoples [2004] FCA 298 (23 March 2004) [7].

43 [2005] FCA 777 (10 June 2005) [44] (French J).

44 Ibid [1073]. In 2010, the Full Court of the Federal Court of Australia indicated that, had the matter been properly before them, their Honours would not have turned down the claim for lack of precision: Sampi v Western Australia (2010) 266 ALR 537, 570-1 [118] (North and Mansfield JJ).

45 (2010) 270 ALR 564, 683 [512] (Finn J).

46 Ibid 687 [532]. 
Despite this his Honour noted: 'I have difficulty in understanding what the "protect" rights actually comprehend in the marine context of Torres Strait. The uninformative generality of the language of the rights exaggerates the difficulty. ${ }^{47}$ As a result ' $\mathrm{t}$ ] he rights, in short, claim an unelaborated entitlement to do whatever is appropriate in the circumstances to protect but which falls short of controlling the access and conduct of others. ${ }^{48}$ The claim failed, in part because of an assumption one can only protect through control, in part because the level of individuation of rights required was absent. ${ }^{49}$

This is not to say that rights to protect have never been recognised. However, they are generally assessed in light of the quality of control that is claimed. Low-level 'rights to protect' can be recognised where they are of a 'non-exclusive' nature. They may in that context involve actions of a 'physical character.' What is involved in 'protection' must also be itemised. In AttorneyGeneral (NT) $v$ Ward, the native title determination included a right to have access to, maintain and protect' the sites of significance within the claim area, which the Court found did not amount to a right to exclude, but could involve 'physical activities on the site to prevent its destruction'. ${ }^{50}$ In Daniel $v$ Western Australia the determination included:

a right to protect and care for sites and objects of significance ... (including a right to impart traditional knowledge concerning the area, while on the area, and otherwise, to succeeding generations and others so as to perpetuate the benefits of the area and warn against behaviour which may result in harm, but not including a right to control access or use of the land by others). ${ }^{51}$

47 Ibid 687 [534]. Cf Neowarra $v$ Western Australia [2003] FCA 1402 (8 December 2003) [484] (Sundberg J).

48 Akiba (2010) 270 ALR 564, 688 [535] (Finn J).

49 This fragmented view of native title has become a part of common law jurisprudence: see the provisions of the former Foreshore and Seabed Act 2004 (NZ). The 'right to protect' has another life in international law as it may form the basis of intervention to protect the rights of human populations in sovereign states. Anne Orford has pointed out some of the ways in which protection of population has come to authorise the work of the United Nations. Orford's recent work points to the ways in which the United Nations has attempted to separate questions of protection from those of sovereignty: see Anne Orford, International Authority and the Responsibility to Protect (Cambridge University Press, 2011) ch 3. For a political and economic analysis of this argument in the context of international law, see Sundhya Pahuja, Decolonising International Law: Development, Economic Growth and the Politics of Universality (Cambridge University Press, 2011) ch 4.

50 (2003) 134 FCR 16, 24 [25] (Wilcox, North and Weinberg JJ).

51 [2005] FCA 536 (2 May 2005) [6] (Nicholson J). 
This was one element of an order composed of upward of 20 precisely defined, low-level rights, most of which concerned matters of access (for example, a right to go into the native title area and take black, yellow, white and red ochre). Similarly, in Neowarra $v$ Western Australia ('Neowarra'), ${ }^{52}$ Sundberg J included in the determination of native title a right to visit places and protect them from physical harm. He stated that:

The evidence is that maintaining places of importance involves low impact activities such as visiting, checking for damage, smoking, speaking to the Wanjina [spirit ancestor] and repainting. Activities of this type are not inconsistent with a pastoralist's right to graze stock. In the event of a clash of activities at or near a particular site, the pastoralist's right will prevail. Protection is directed to the prevention of damage to sites. This might involve Aboriginal presence when a busload of tourists visits a painting location, to ensure that the site is not damaged. ${ }^{53}$

At one level in these cases there is a simple or straightforward failure to acknowledge another law. What, after all, is a claim for recognition of a right to speak for country but a claim for a recognition of authority of law? In what sense can monitoring the behaviour of busloads of tourists be considered a meaningful acknowledgement of lawful relations? While, of course, judicial pronouncements such as those of Neowarra could be attributed to a lack of care, in the last two sections we have offered an account of how this failure of acknowledgement is shaped both through the long history of jurisdictional thinking and through a specific practice of interpretation. In the next section we turn to the quality or character of legal relations suggested in the jurisprudence of s 223 .

\section{The Quality of Meeting}

In order to address the relation between jurisdiction and conduct it is necessary to consider what can be said about the quality of the mode and manner of engaging lawful relations. Here we address the quality of lawful relations in terms of the craft and quality of the technologies of jurisdiction. In jurisdictional terms s 223 can be understood as a device or legal technology capable of authorising, locating, changing, or shaping legal relations. It is a technology or craft of jurisdiction that establishes the repertoires and quality

\footnotetext{
52 [2003] FCA 1402 (8 December 2003).

53 Ibid [484].
} 
of lawful engagement. ${ }^{54}$ One example of a jurisdictional device from the history of the common law is the writ of prohibition. This was a writ used by the common law to take jurisdiction from other jurisdictions. The writ of prohibition, however, presupposes that the purpose of such a device is to order relations between acknowledged and existing laws - to configure a meeting point. Historically, that meeting point might have been, for example, between common law and ecclesiastical law. It is easier to see something like this writ functioning as a technology or device of jurisdiction, and actively crafting legal relations, because we recognised both jurisdictions. It is a different matter, however, to see something like s 223 as a jurisdictional device when one of the laws remains unacknowledged.

While s 223 can be understood as a jurisdictional device, it is not tied to a practical activity in the same way as a writ. To draw on an old analogy in law, it operates more as a way of elaborating a grammar of lawful relations. A grammar of lawful relations can be considered as a formalisation of the repertoires of the conduct. For some this is best understood in terms of an external mode of ordering, for others it reveals an internal structure. Here we think of grammar more experientially as part of an activity or form or conduct of life.

The most persistent use of the grammatical analogy of law belongs to the schools of analytical jurisprudence. Jeremy Bentham, for example, divided law between its adjective and substantive forms in order to distinguish between means and ends of law. ${ }^{55}$ Adjective law, procedure and evidence, was concerned with providing the efficient means of achieving the substantive (nominative) aims of law. 'Positivist' traditions of legal thought have framed both the adjective and substantive concerns of law in terms of social fact. The jurisprudence of s 223 has followed this general understanding of law in so far as it has been focused on the proof of the 'content' of native title in terms of the individual elements of that section. More broadly, this conduct turns on

54 On the technologies or devices of jurisdiction in particular, see Dorsett and McVeigh, Jurisdiction, above $\mathrm{n} 5$.

55 Jeremy Bentham, 'Principles of Judicial Procedure, with the Outlines of a Procedure Code' in John Bowring (ed), The Works of Jeremy Bentham (William Tait, 1843) vol 2, 1. Bentham understood substantive (noun-centred) law in two ways. At one level it is understood as purposive - to achieve the end of maximum utility. At another level - that of form substantive law is the substance of the laws formed and understood as command and rule. See Albert Kocourek, 'Substance and Procedure' (1941) 10 Fordham Law Review 157; William Twining, Rethinking Evidence: Exploratory Essays (Cambridge University Press, $2^{\text {nd }}$ ed, 2006) 75-81; George P Fletcher, The Grammar of Criminal Law - American, Comparative and International: Volume One: Foundations (Oxford University Press, 2007) 194-7, 248-51. 
the proof of a relationship between the NTA and the broader common law and proof of a relationship between the claimants of native title and their relation to Indigenous laws and jurisprudence.

No doubt much of the understanding of the relationship of law in the jurisprudence of s 223 is adjective in ambition. However, viewed in terms of the conduct of the meeting of laws, the jurisprudence of s 223 invites a form of scepticism or doubt over the possibility of a meeting of laws. Since s 223 lacks substance it establishes its relationship of laws in terms of the proof of the physical activities observed (social fact). Such activities are understood in terms of the 'social facts' of custom that most closely resemble our dominant understandings of property. Indeed, as stated in Yanner $v$ Eaton, 'an important aspect of the socially constituted fact of native title rights and interests that is recognised by the common law is the spiritual, cultural and social connection with the land.'56

Stanley Cavell has argued that scepticism should not be characterised only in terms of a lack of knowledge of the existence of an other. For Cavell, and us, the concern is one of ethos or conduct. Here the issue is not what is known, but of the ability or inability to yield or be commanded by what is known. It is a question of too much, not too little, knowledge. ${ }^{57}$ Viewed as a question of conduct, the technical expression of s 223 appears more as a contest of laws than as a mode of inquiry into the creation. One of the difficulties in finding a meeting of laws lies, then, within the limits of the conduct and resources of common law jurisdictional practices. In the sceptical form of a jurisdictional engagement of laws it might be that all we are left with by way of a meeting of laws is evidence of social practices of Indigenous laws that are understood as not inconsistent with state law (here, Australia). ${ }^{58}$ Within this jurisdictional arrangement an Indigenous law and jurisprudence that is understood as arising from the land is turned into a matter of following observed practices.

Influential and important as Bentham's adjective understanding of the conduct of law as social fact has been, there are other ways within the common law tradition of understanding the jurisdictional form of law. Stanley Cavell's emphasis on the sceptical ethos generated by the requirements of proof draws attention to the ways in which forms of conduct are linked to practices of law. In terms of the analogy of a grammar we have used, the concern with conduct and activity invites the consideration of procedure and

\footnotetext{
56 (1999) 201 CLR 351, 373 [38] (Gleeson CJ, Gaudron, Kirby and Hayne JJ).

57 See Stanley Cavell, The Claim of Reason: Wittgenstein, Skepticism, Morality, and Tragedy (Clarendon Press, 1979) 496.

58 See Dorsett, 'Since Time Immemorial', above n 17, 53-9.
} 
evidence as being adverbial rather than adjectival. By emphasising the adverbial quality of law, we note the ways in which procedure can be related to a dynamic (verb-centred) account of legal actions. ${ }^{59}$ Section 223 is adverbial in the way that it shapes the conduct of the meeting of laws - it speaks to the quality and the substance of the engagement of laws. This can be clearly seen in the way in which the Australian courts understood the right, or authority, or jurisdiction, to speak for, or protect, country. However, noting this, as Cavell's insight makes clear, need not make the creation or maintenance of lawful relations any easier. It does, however, make the quality of the conduct of the relationship of laws central to the understanding of the meeting of laws.

One example of changing the quality of the engagement of laws might be the proposed amendments to the NTA, introduced into the Senate by the Greens in 2011 in response to calls from various quarters, in particular by the Social Justice Commissioner, Tom Calma. ${ }^{60}$ The Bill (which the majority of the Senate Legal and Constitutional Affairs Legislation Committee has recommended not be passed by the Senate $)^{61}$ proposed a number of new sections, relevantly here ss $61 \mathrm{AA}-61 \mathrm{AB}$, as well as amendments to s 223 . Sections 61AA-61AB would have been arguably the most crucial changes to the Act since its introduction. These sections provided for presumptions of continuous connection in relation to applications for native title determinations.

Section 61AA created a new presumption in relation to an application for determination under $\mathrm{s} 61$. If a number of elaborated 'circumstances exist' then it must be presumed that the customs and laws acknowledged are those that were acknowledged at sovereignty, that the native title holders have a connection to land and waters by the traditional laws and customs and that the rights

59 A lot of energy has been invested in what often turn out to be rival accounts of law and legal theory. In an abbreviated way this distinction is drawn here on the sense that the common law tradition is a dynamic 'living' law. See Eugene Ehrlich, Fundamental Principles of the Sociology of Law (Walter L Moll trans, Harvard University Press, 1936) 486-7; Arthur J Jacobson, 'Hegel's Legal Plenum' (1989) 10 Cardozo Law Review 877. The distinction offered here is heuristic.

${ }^{60}$ Native Title Amendment (Reform) Bill 2011 (Cth); Aboriginal and Torres Strait Islander Social Justice Commissioner, Native Title Report 2009 (Australian Human Rights Commission, 2009) ch 3. Further suggestions included clarifying the meaning of 'traditional' and the matter of what constitutes 'substantially uninterrupted': at 85-7. The Commissioner is not the only one of this opinion: see, eg, Explanatory Memorandum, Native Title Amendment (Reform) Bill 2011 (Cth) 2, 7, acknowledging that proposed amendments are in line with the opinion of Chief Justice Robert French.

61 Senate Legal and Constitutional Affairs Legislation Committee, Parliament of Australia, Native Title Amendment (Reform) Bill 2011 Report (2011) 37-9 [3.82]-[3.92]. 
are capable of recognition by the common law. Reversing the burden of proof, it could be argued, acknowledges a relationship of laws. However, while these reforms proposed to reverse some of the burden of proof, the circumstances which must have existed for this presumption to apply are not easy in themselves to show. In particular, s $61 \mathrm{AA}(1)(\mathrm{c})$ required that the claimants need to show that they 'by the laws acknowledged and the customs observed, have a connection with the land or waters the subject of the application'. Section $61 \mathrm{AB}(1)$ provided that if the presumption is established, then it could only be set aside by evidence of a substantial interruption in the acknowledgement or observance of those customs. This included as relevant whether the reason for the interruption was the actions of a non-Indigenous party, be it the Crown or a private person $(\mathrm{s} 61 \mathrm{AB}(2))$.

Considered as a question of conduct, reforming the burden of proof addresses the quality or ethos of lawful relations. It could, perhaps, be taken as developing an ethos that is no longer dominated by scepticism over the existence of other laws. The common law of Australia might be able to receive, and live with, more knowledge of Indigenous laws and jurisprudence. However, even if the ethos of the common law is reformed, it also remains the case that the quality of conduct is tied to the jurisdictional practice of the common law. The proposed reforms do not change this. It is here we reach a limit of jurisdictional practice.

The distinction between an adjectival and adverbial understanding of procedure and proof was introduced in this section as a heuristic device to show some of the ways in which s 223 has been interpreted has been shaped by commitments to certain forms of conduct. Such distinctions also inevitably - raise more general concerns about the mode and manner of engaging lawful relations through the common law. To emphasise the adverbial quality of procedure is also to emphasise law as an activity or conduct, rather than simply as a social fact.

\section{Vi The Meeting Places of the Jurisprudent}

In this essay, we have been elaborating a jurisdictional account of the meeting place of law from within common law jurisprudence. In making the quality of the meeting of laws visible, we have also begun to elaborate a concern that a failure to pay attention to the jurisdictional form of law is part of a failure to attend to, and take responsibility for, the conduct of the meeting of laws. Here we address this concern directly as part of the office (or responsibility) of the jurisprudent. We consider the work of two jurisprudents whose concern with the responsibility for the conduct of meeting of laws is addressed through a 
concern with a grammar of lawful actions. The work of Jeremy Webber has drawn attention to the importance of the commonality of custom between common law and Indigenous laws, and that of Peter Rush has warned of the loss of jurisdictional form and of the interior experience of the common law. They can deepen accounts of the ways in which the meeting of laws has been practiced through s 223 .

In a number of essays reflecting on forms of engaging Indigenous and non-Indigenous law, Jeremy Webber has argued that it is necessary to develop modus vivendi between laws. ${ }^{62}$ From the standpoint of the common law tradition this involves developing both the internal customary resources of the common law tradition and a sense of justice in the engagement of laws. The emphasis on the customary quality of the common law draws the engagement of laws and, so it might be imagined, s 223, into the domain of experience and of conduct. Webber writes:

Law is grounded, fundamentally, in the practices of particular societies. All law, even legislation, finds its meaning in interpretive relationship to those practices. To understand law is to understand norms' relationship to the web of human interaction in a given society. ${ }^{63}$

It also, for Webber, allows for the comparison and relating of Indigenous and non-Indigenous forms of legal ordering. Framing law in terms of customary conduct allows for the recognition of the plurality of practices of law even when they are in conflict. It is through the 'inter-subjective' recognition of the locality of the practices and for the justness in the forming of relations between and across laws that we begin the engagement of Indigenous and non-Indigenous laws.

In Webber's account, custom is understood in terms of a grammar. In a broad sense (attributed to Wittgenstein) grammar includes:

not just the express rules that purport to regulate the use of a language, but rather the way in which a language's structure and terms enable and constrain what a competent speaker can say intelligibly. Through the distinctive grammar

62 Jeremy Webber, 'Relations of Force and Relations of Justice: The Emergence of Normative Community between Colonists and Aboriginal Peoples' (1995) 33 Osgoode Hall Law Journal 623; Jeremy Webber, 'Legal Pluralism and Human Agency' (2006) 44 Osgoode Hall Law Journal 167; Jeremy Webber, 'The Grammar of Customary Law' (2009) 54 McGill Law Journal 579.

63 Webber, 'The Grammar of Customary Law', above n 62, 581. 
of each customary legal order, much of the normative content of that law is encoded, organized, and expressed. ${ }^{64}$

What is customary is in part a common pattern or narrative of action; in part a shared grammar of law; and in part a concern with the forms of pragmatic engagement (in good faith) of lawful relations. ${ }^{65}$ For Webber it is the analogy of law as part of a customary form and practice of language that allows for the negotiation of recognition of commonality of laws. In turn, it is the commonality of customary form and the potential commonality of the grammar of lawful relations that makes negotiation and exchange the point of focus of the meeting of laws. In such an account, s 223 of the NTA would be patterned into the customary laws of both the common law and of Indigenous law. It is this that allows for the possibility of the negotiation of lawful relations. For Webber, it is the commonality of customary law that allows, or will allow, for the perfection of the meeting of laws.

In this essay, we have emphasised the idiom and the form of jurisdiction, rather than the commonality of custom. We have done so in order to hold the meeting of laws to the technical and institutional forms of common law. Where Webber's account is comparative and stresses the inter-subjective understanding of the languages of law, the jurisdictional approach we have taken here offers a reminder that the engagement of laws is conducted from within one order of law in relation to another. In this analysis it is the exercise of jurisdiction - and the emphasis we have placed on its technical and adverbial quality - that marks the meeting of laws. Attending to jurisdiction stresses the immanent quality of the resources of lawful relations and that meaning and responsibility are generated through the conduct of law.

Where Webber formulates a meeting of laws in terms of negotiated agreement of relations, Rush concentrates on the ways in which the common law has struggled to come to terms with the meeting of laws. The grammar of lawful actions, for Rush, is not a grammar that is common to all customary laws, it is a grammar of jurisdiction and the institutional forms of action. What interests Rush is the sense in which the possibility of lawful relations is tied to the experience of law. For Rush, the meeting of laws is not held in place with the promise of inter-subjective relations. Indeed, for Rush, much of the common law tradition is experienced as anxiety and trauma. Part of this anxiety relates to ways in which the High Court refuses to address the status

64 Ibid 618-19 (citations omitted).

65 Ibid 619-21. See also Bernard S Jackson, Semiotics and Legal Theory (Routledge \& Kegan Paul, 1985). 
of its own authority - sovereignty - as well as that of Indigenous laws and jurisdictions. The trauma of the common law - as judgments in Mabo, Wik, and Ward have elaborated - relates to the possibility of the common law continuing to ground its own authority in the absence of a direct relationship with justice (Brennan J in Mabo) or with common law tradition (Gummow J in Wik) or with ability to transform the law (McHugh J in Ward). One of the consequences of the High Court of Australia's insistence that any analysis of native title start from s 223 is that the High Court no longer specifically addresses concerns about its own authority. ${ }^{66}$ From this position - as the jurisprudence of $s 223$ continues to demonstrate - there is no guarantee that the grammar of law is capable of articulating either a common understanding of custom (Webber) or experience (Rush). In this light, the sceptical jurisprudence of conduct articulated in the wake of s 223 might be viewed in terms of a loss of confidence in the common law.

\section{Concluding Comments}

Attending to the limits of what can said or experienced through articulating a jurisdiction leads to the closing remarks of this essay. We turn, briefly, to the ethic of responsibility of jurist and jurisprudent. In this essay we have investigated a number of ways in which native title as a jurisdictional device creates forms of lawful relation. The adverbial understanding of jurisdiction does not address questions of substance so much as give us forms of action, description, and engagement. It is clear that many native title determinations have created relations that acknowledge very little Indigenous law and jurisprudence. We close this essay with some comment about the ethic of responsibility for such jurisdictional forms. Here, Max Weber's lecture 'Politics as Vocation' provides a somewhat unlikely point of departure for linking our jurisdictional account of s 223 of the NTA with an ethic of responsibility or conduct of office. ${ }^{67}$

Within the common law tradition the office of jurist has had responsibility for the naming, ordering, and locating of legal relations. The office of jurisprudent is concerned with the conduct of law. The practices that shape the

66 Shaunnagh Dorsett and Shaun McVeigh, 'Just So: "The Law Which Governs Australia is Australian Law"' (2002) 13 Law and Critique 289.

67 Max Weber, 'Politics as Vocation' in David Owen and Tracy B Strong (eds), Max Weber: The Vocation Lectures (Rodney Livingstone trans, Hackett Publishing, 2004) 32; Jeffrey Minson, 'Civil Prudence, Sovereignty and Citizenship in the Justification of Civil Forfeiture' (2006) 29 University of New South Wales Law Journal 61. 
jurisdictional form of native title are part of a long tradition of engagement of customary or common laws. ${ }^{68}$ Weber's point of departure for an ethic of office is to link office both to institutional activity and to a number of external and internal realities. It is an ethic of responsibility that is framed in terms of finding the appropriate internal qualities to meet external realities. His analysis - and ours - is marked by the limits that office imposes. For us such limits relate to official forms of conduct associated with the exercise of jurisdiction as a craft or practice of the creation and limit of lawful relations. For Weber the distinction that he wants to hold on to is between an ethic of responsibility that addresses what is done, as opposed to an ethic of conviction that is concerned with good intention (or with the representation of justice). The ethics of conviction is criticised by Weber for its willingness to engage subjective predisposition (and conscience) against an ethic of office or jurisdiction. This might be one way of responding to the form of the common law - provided that the office of judge and jurisprudent remains alive to the concerns of lawful relations.

In part, Weber's ethic of responsibility involved taking responsibility for the world as one finds it. This, it might be imagined, could require acknowledgement that the jurisdictional practices of native title have created a meeting of laws that continues to expect little of those who follow the common law. It would also involve the acknowledgement that the jurisdictional practices of the common law pursue incompatible ends or ends that are followed with little understanding of Indigenous laws and jurisprudence. It might also be the case the administrative and bureaucratic impetus of native title is destined to defeat an engagement of laws and to leave the common law meeting place of laws empty of forms of conduct. An ethic of responsibility that only did this would be ignoring the responsibility of the jurist to elaborate lawful relations and the jurisprudent to find forms of conduct appropriate to a meeting of laws.

68 Bradin Cormack, A Power to Do Justice: Jurisdiction, English Literature, and the Rise of Common Law, 1509-1625 (University of Chicago Press, 2007) ch 3. 